\title{
Meningitis with polymerase chain reaction for varicella zoster positivity in cerebrospinal flid of a young immunocompetent adult
}

\author{
Pooja Gupta, Rajeev Ranjan, C. S. Agrawal, Muralikrishnan K, Nikhil Dave, Davinder Singh Rana \\ Department of Neurology, Sir Ganga Ram Hospital, New Delhi, India
}

\section{ABSTRACT}

Meningitis caused by varicella zoster virus (VZV) is quite rare among young immunocompetent adults though immunocompromised patients are often seen to be affected by reactivation of VZV presenting with primary clinical features of dermatomal rashes and neurological sequelae. Here, we report the clinical scenario of a young, healthy male who had presented with fever, headache, and onset of dermatomal rashes later than the fever and was eventually diagnosed to be a case of VZV meningitis. We would like to highlight the fact that even young immunocompetent patients though rarely, might contract VZV meningitis and clinicians should have a high index of suspicion and keen eyes to catch the more obvious features of VZV infection on complete physical examination and must not harbor any reservations in ordering polymerase chain reaction for VZV DNA or initiating aggressive antiviral therapy.

Key words: Immunocompetent, meningitis, varicella zoster virus

\section{Introduction}

Infections by herpes viruses (herpes simplex Type 1 or 2, varicella zoster virus [VZV]) are frequent in humans, and such viruses tend to persist within cranial nerves, dorsal roots, and autonomic ganglia causing latent infections by virtue of reactivation. ${ }^{[1-3]}$ Reactivation of VZV mainly presents with rash and pain affecting the entire dermatome and less frequently a zoster sine herpete. ${ }^{[1-3]}$ VZV infection of the central nervous system (CNS) such as encephalitis, meningitis, myelitis, or vasculitis occurs rarely but is feared because of the numerous unfavorable outcomes of such presentations. ${ }^{[1,3,4]}$ Reactivation of VZV is seen predominantly in older individuals and/or immunocompromised patients..$^{[1-3]}$ CNS infection with $\mathrm{VZV}$ in young immunocompetent adults is rare and

\section{Address for correspondence:}

Dr. Pooja Gupta, Department of Neurology, Sir Ganga Ram Hospital, Room No. F/34, $1^{\text {st }}$ Floor, Old Building Block, Old Rajinder Nagar,

New Delhi - 110 060, India.

E-mail: gupta.pooja0108@gmail.com

\begin{tabular}{|l|l|}
\hline \multicolumn{2}{|c|}{ Access this article online } \\
\hline Quick Response Code: & Website: \\
\hline & www.ruralneuropractice.com \\
\cline { 2 - 3 } & \\
\hline
\end{tabular}

unexpected, and only very few cases have been described so far in the world literature..$^{[5-9]}$ We bring to limelight, the scenario of a young immunocompetent patient with VZV meningitis.

\section{Case Report}

A 33-year-old healthy Indian male employed as a software engineer developed intermittent holocranial throbbing headache, which soon progressed to severe continuous headache, associated with fever, photophobia, and vomiting for a duration of 3 days. He also complained of rashes over the skin of his left shoulder blade and left side of his body which was of the same duration. There was no past history of similar illness, contact with people having similar complaints, or chicken pox. There was no history of any other comorbidity. On examination, the patient was febrile, had neck stiffness and photophobia, and was found to have rashes along the cutaneous distribution

This is an open access article distributed under the terms of the Creative Commons Attribution-NonCommercial-ShareAlike 3.0 License, which allows others to remix, tweak, and build upon the work non-commercially, as long as the author is credited and the new creations are licensed under the identical terms.

For reprints contact: reprints@medknow.com

How to cite this article: Gupta $P$, Ranjan R, Agrawal CS, Muralikrishnan K, Dave N, Rana DS. Meningitis with polymerase chain reaction for varicella zoster positivity in cerebrospinal flid of a young immunocompetent adult. J Neurosci Rural Pract 2016;7:591-3. 
of two lower intercostal nerves of the left side. Rest of general and systemic examination was unremarkable. His complete blood count was unremarkable except for raised erythrocyte sedimentation rate $\left(30 \mathrm{~mm} / 1^{\text {st }} \mathrm{h}\right)$. Renal function tests, liver function tests, and serum C-reactive protein were also reported normal. Serologies for dengue, typhoid, malaria, infectious mononucleosis, toxoplasma, rubella, cytomegalovirus, and herpes simplex antibodies were negative. Human immunodeficiency virus (HIV) serology was negative. Magnetic resonance imaging of the brain was normal. The cerebrospinal fluid (CSF) analysis showed cell count of 535 cells/ $\mu$ l CSF (differential count: 99\% lymphocytes, 01\% polymorphs), CSF protein was $115 \mathrm{mg} / \mathrm{dl}$, CSF glucose was $34 \mathrm{mg} / \mathrm{dl}$, and plasma glucose $76 \mathrm{mg} / \mathrm{dl}$. CSF adenosine deaminase level was within normal limit (1 U/L). CSF Grams stain, Ziehl-Nielsen's acid-fast bacilli stain, India ink stain, cryptococcal antigen, common bacterial antigen assay (Haemophilus influenzae B, Streptococcus Group B, Streptococcus pneumoniae, Neisseria meningitidis A CYW 135, N. meningitidis B, and Escherichia coli), venereal disease research laboratory, and polymerase chain reaction (PCR) for tuberculosis were negative. CSF- PCR assays for herpes simplex I and II, enterovirus, and Mycobacterium tuberculosis were negative. CSF culture was negative for pyogenic organisms and tuberculosis. However, PCR for VZV conducted on blood and CSF was reported positive. He was treated with a broad spectrum antibiotic (ceftriaxone) and intravenous acyclovir (dose of $10 \mathrm{mg} / \mathrm{kg}$ body weight every $8 \mathrm{~h}$ ) for 6 days. Gradual improvement in the condition of the patient was observed from $3^{\text {rd }}$ day after initiation of parenteral acyclovir. He was discharged after in stable condition on oral acyclovir for 15 days.

\section{Discussion}

Most neurological complications caused by VZV can occur in both primary and reactivated VZV although they seem to appear more frequently in herpes zoster than in VZV. Both immunocompetent and immunocompromised patients may suffer from these neurological complications, but they appear to be more frequent and more severe in the latter group. The common neurological complications associated with herpes zoster are postherpetic neuralgia, myelitis, encephalitis, ventriculitis, aseptic meningitis, and white-matter disease.$^{[10]}$ Meningitis is a rare complication of VZV infection In a review of 859 patients with varicella-zoster infection; meningitis was reported in only $0.5 \%$ within 60 days of diagnosis incidence increases with age including 2.5 cases/1000 in ages 21-50 versus 10.1 cases/1000 in those older than 80 years. ${ }^{[11]}$ The incidence is increased in HIV-seropositive patients including 29.4 cases/1000 person-years as compared to the HIV-seronegative patients with 2.0 cases/1000 person-years. ${ }^{[12]}$ Although the incidence of varicella and complications has decreased since the licensure of the vaccine, there may be breakthrough cases of varicella with aseptic meningitis and transient sensorineural hearing loss. ${ }^{[13]}$ Patients with VZV meningitis may suffer from high fever, severe headache, cervical rigidity, seizure, ataxia, hemiplegia, and even coma; these symptoms may appear within days after the appearance of the skin lesion and sometimes without skin lesions also. CSF shows increased cell counts and elevated protein levels in the $\mathrm{CSF}^{[10]}$ using sensitive laboratory analyses (e.g., PCR and detection of intrathecal production of specific antibodies), recent epidemiological studies found a portion of $5-29 \%$ of VZV in aseptic meningitis and encephalitis and it has been suspected that VZV infections had been underestimated in earlier publications. ${ }^{[9]}$ Nevertheless, in immunocompetent patients without neurological deficits (as in our case), VZV meningitis is rare. We, therefore, highlight the importance of considering VZV as a possible cause for meningitis even in previously healthy young patients and the recommended diagnostic lumbar puncture. Detailed CSF diagnostic procedures including PCR and detection of intrathecal synthesis of antiviral antibodies (especially for VZV and herpes simplex viruses) should be considered even though CSF cell count and total protein seem to indicate a bacterial infection. ${ }^{[14]}$ Since herpes zoster is a viral disease, conservative care or acyclovir administration is the routine treatment, and steroid therapy is employed as an optional addition. The administration of acyclovir within $48-72 \mathrm{~h}$ of the appearance of zoster effectively relieves acute pain and the vesicles, induces a higher rate of remission, and deters the virus from spreading throughout the patient's body, and they usually show a full recovery without developing other complications. ${ }^{[10]}$

\section{Financial support and sponsorship}

Nil.

\section{Conflicts of interest}

There are no conflicts of interest.

\section{References}

1. Gilden DH, Kleinschmidt-DeMasters BK, LaGuardia JJ, Mahalingam R, Cohrs RJ. Neurologic complications of the reactivation of varicella-zoster virus. N Engl J Med 2000;342:635-45.

2. Steiner I, Kennedy PG, Pachner AR. The neurotropic herpes viruses: Herpes simplex and varicella-zoster. Lancet Neurol 2007;6:1015-28.

3. Mueller NH, Gilden DH, Cohrs RJ, Mahalingam R, Nagel MA. Varicella zoster virus infection: Clinical features, molecular pathogenesis of disease, and latency. Neurol Clin 2008;26:675-97, viii. 
4. Gilden D, Cohrs RJ, Mahalingam R, Nagel MA. Varicella zoster virus vasculopathies: Diverse clinical manifestations, laboratory features, pathogenesis, and treatment. Lancet Neurol 2009;8:731-40.

5. Jhaveri R, Sankar R, Yazdani S, Cherry JD. Varicella-zoster virus: An overlooked cause of aseptic meningitis. Pediatr Infect Dis J 2003;22:96-7.

6. Leahy TR, Webb DW, Hoey H, Butler KM. Varicella zoster virus associated acute aseptic meningitis without exanthem in an immunocompetent 14-year-old boy. Pediatr Infect Dis J 2008;27:362-3.

7. Habib AA, Gilden D, Schmid DS, Safdieh JE. Varicella zoster virus meningitis with hypoglycorrhachia in the absence of rash in an immunocompetent woman. J Neurovirol 2009;15:206-8.

8. Klein NC, McDermott B, Cunha BA. Varicella-zoster virus meningoencephalitis in an immunocompetent patient without a rash. Scand J Infect Dis 2010;42:631-3.

9. Douglas A, Harris P, Francis F, Norton R. Herpes zoster meningoencephalitis: Not only a disease of the immunocompromised? Infection 2010;38:73-5.

10. Kim MA, Yu RM, Kim KH, Chung HJ. A case of acute aseptic meningitis associated with herpes zoster. Korean J Pediatr 2009;52:705-9.

11. Hope-Simpson RE. The nature of herpes zoster: A long-term study and a new hypothesis. Proc R Soc Med 1965;58:9-20.

12. Buchbinder SP, Katz MH, Hessol NA, Liu JY, O’Malley PM, Underwood R, et al. Herpes zoster and human immunodeficiency virus infection. J Infect Dis 1992;166:1153-6.

13. Schwab J, Ryan M. Varicella zoster virus meningitis in a previously immunized child. Pediatrics 2004;114:e273-4.

14. Pasedag T, Weissenborn K, Wurster U, Ganzenmueller T, Stangel M, Skripuletz T. Varicella zoster virus meningitis in a young immunocompetent adult without rash: A misleading clinical presentation. Case Rep Neurol Med 2014;2014:686218. 